\title{
REPORT
}

\section{A Report on the INSEE Ninth Biennial Conference on Sustainability, Institutions, Incentives: Voices, Policies and Commitments}

\author{
Nandan Nawn *
}

Research on economics of the environment is carried out through mostly the orthodox or heterodox paradigm. The orthodox paradigm is rooted in the neoclassical framework, while the heterodox paradigm follows a more inclusive, transdisciplinary approach that includes political ecology, environmental history, and environmental sociology. This difference in quite evident in many locations of the Global North, such as Europe. It can be witnessed by means of simple and analytical indicators like the journals listed by professional societies: Environmental Policy and Governance, by the European Society for Ecological Economics (ESEE) and Environmental and Resource Economics, by the European Association of Environmental and Resource Economics (EAERE). The ESEE's own journal Environmental Policy and Governance characteristically includes papers on values, politics, and institutions even within its limited scope. The EAERE's own journal Environmental and Resource Economics typically includes papers on optimal control, bargaining, experimental economics, marginal abatement costs, and dynamic efficiency. Interestingly, Environment and Development Economics is listed by both societies under 'publications'.

Such compartmentalization into the orthodox and heterodox paradigms is virtually absent in the Indian context in terms of structure or function. The Indian Society for Ecological Economics (INSEE) represents both paradigms - it has had an agricultural economist and a hydrologist as

\footnotetext{
* Head, Department of Policy Studies, TERI School of Advanced Studies, 10 Vasant Kunj Institutional Area, New Delhi, India 110070; Secretary, INSEE (2016-18); and Organizing Secretary, Ninth Biennial Conference of INSEE; nnletter@gmail.com

Copyright (C) Nawn 2018. Released under Creative Commons Attribution-NonCommercial 4.0 International licence (CC BY-NC 4.0) by the author.

Published by Indian Society for Ecological Economics (INSEE), c/o Institute of Economic Growth, University Enclave, North Campus, Delhi 110007.

ISSN: 2581-6152 (print); 2581-6101 (web).

DOI: https://doi.org/10.37773/ees.v1i2.48
} 
president. This inclusiveness is evident in the title of its journal, Ecology, Economy and Society, and in the variety of the programmes it has organized. It was reflected in the theme of its ninth biennial conference, 'Sustainability, Institutions, Incentives: Voices, Policies and Commitments'; and in the titles of parallel sessions-'Aquatic, Wetland, and Terrestrial Ecosystems' (sustainability); 'Governance of Local Common Pool Resources' (institutions); 'Behavioural Responses' (incentives); 'Politics, Resistance, and Movements' (voices); 'Urban Housing and Sanitation' (SDGs and the Global South); and 'Impacts of Climate Change'.

At the conference, held over 7-10 November 2017, presented papers adopted a wide variety of methods and associated theoretical frameworks. A paper that explored the use of socio-economic and energy technology systems to limit climate change to an exogenously given level employed the computational general equilibrium (CGE) model. Another used a zeroinflated negative binomial model to evaluate the impact of floods on human development and income. Several used varieties of other econometric models: one on assessing sanitation development for meeting the relevant SDG employed simple correlation; another on urban sanitation in Indian slums used regression; one on irrigation used the institutional analysis and development (IAD) framework; and another on the establishment of an industrial project adopted political economy.

The organizers chose to foreground the fact that the goal of sustainability is intricately linked with human behaviour and anthropogenic pressures, which are often transmitted through institutions. This called for bringing together the natural sciences, social sciences, and governance in an interdisciplinary engagement. In choosing the theme, the organizers acknowledged the phenomenal rise in the importance of governance and, hence, institutions in the matter of public policy; this rise in importance traverses virtually all areas and, in particular, those at the interface of environment and development. The organizers felt that due attention is not paid to the important task of creating a space for discussing how individuals and groups voice their choices through formal and informal mechanisms and how they participate in decision-making. This prompted the choice of the Kerala Institute of Local Administration (KILA) at Thrissur as the venue, a state institution for local governance, located not only in a nonmetro city but also in a state that has witnessed movements and policy negotiations in the distant past (Silent Valley) and the recent past (Western Ghats) and is witnessing movements and negotiations now (Athirappilly). This rich history of movements and negotiations was reflected in the programme. 
Local researchers made presentations in parallel sessions titled 'EconomicEcological Systems in Kerala'. In one panel, titled 'Environment, Climate Change, Biodiversity and Local Governance', and chaired by the Director, Directorate of Environment and Climate Change, Government of Kerala, speakers ranged from the Secretary of Kerala State Biodiversity Board to the President of the Meenangadi Gram Panchayat to representatives of the Kerala Sasthra Sahithya Parishad to the Secretary of the Forum of Environment Journalists in India.

A second panel discussion was titled 'Setting the Conservation and Development Agenda for the Western Ghats, India' and moderated by a former Head of the Department of Wildlife of the Kerala Forest Research Institute. It involved three officials of the Government of Tamil Nadu: the Additional Chief Secretary, the Principal Chief Conservator of Forests, and the Chairman of the State Environment Impact Assessment Authority. In another panel, sponsored by the Intergovernmental Panel on Climate Change (IPCC), authors of five chapters of the Fifth Assessment Report of the IPCC presented their findings, and carried further the discussion on negotiating with the science-policy interface.

In the discussion titled 'Is there A Global Environmental Justice Movement?', panellists from Spain and India explored how the involvement of different actors-indigenous communities, women leaders, and international non-governmental organizations-affects environmental justice movements. In the panel 'Marine Fisheries Resources and Technology: Some Sustainability and Equity Issues', ecologists and ecological economists discussed developments in methods of assessing fisheries resources and the influence of the notion of 'ecosystem services' in fisheries management. Another panel discussed the role of ecosystem services in improving farm income while ensuring the health of the ecosystem.

Interdisciplinarity was at the core of two panels. In one, panellists were in conversation with each other via a human ecology framework, eschewing abstraction of nature from society (and vice versa) while recognizing that environmental issues are simultaneously technical, social, and political in nature. The other explored the experiences, opportunities, and challenges of doing citizen science in India in environmental and ecological studies.

In the inaugural address, V K Ramachandran (Vice Chairman, Kerala Planning Board) showcased the environmental achievements in the state. In her plenary address, Susmita Dasgupta dealt with the implications of climate change 'threats' felt by those in the coastal zones, with particular reference to Bangladesh. In the second plenary, Eswaran Somanathan discussed the 
roles developing country institutions-community, subnational, national, and global-can and do play in handling environmental matters. M N Murty presented arguments on the use of declining discount rates for evaluating investment projects that have long gestation periods, such as for climate change mitigation. Pavan Sukhdev, in his remarks in the inaugural session, argued in favour of making changes in the ways in which accounting of human well-being is carried out. An inclusive wealth index is one such possibility, on which Anantha Duraiappah spoke.

One of the INSEE's mandates is the capacity-building of young researchers; it is carried out by organizing programmes in its conferences and also otherwise. There were four such programmes. A pre-conference workshop titled 'Researching in Ecological Economics' offered training in designing questionnaires; sampling primary data from field surveys; operational challenges in implementation; and planning and execution of ecological economics research in tropical forests. A session was conducted on 'Strengthening Capacity in Coastal and Marine Biodiversity Management' in association with GIZ. A writer's workshop was conducted in association with Springer. A learning game-Cantor's World-organised in association with UNESCO-Mahatma Gandhi Institute of Education for Peace and Sustainable Development was launched at this conference. This session aimed to show teachers of environmental economics how to use this game to explain the potential of the inclusive wealth index in negotiating with policy trade-offs at both a point of time, say, between health, education, and GDP growth, as well as across time.

In association with the IPCC and the Directorate of Environment and Climate Change of the Government of Kerala, and to engage with the city of Thrissur, seven curtain raiser events were organized in colleges (Vimala College, Dr John Matthai Centre, Sacred Heart College, and St Thomas College) and university departments (College of Forestry, Kerala Agricultural University; Academy of Excellence in Climate Change, Kerala Agricultural University). In each experienced INSEE members engaged with the students.

Performances by Kerala Kathakali and Bamboo Symphony Orchestra, both involving local artists, enchanted the audience. A book exhibition-cum-sale by Sage Publications added more flavour, as did a photo exhibition titled 'The City and the Farms - Agriculture in Peri-Urban Bengaluru' in association with the School of Development, Azim Premji University. 